\title{
Contributing Factors That's Effect to Istishna Mode of Financing Performance at Sharia Banking in Indonesia and Malaysia
}

\author{
Mochammad Jasin ${ }^{1}$, Pudji Astuti², Yayan Alfian Nugraha ${ }^{3}$ \\ \{moch.jasin@uinjkt.ac.id ${ }^{1}$,Pudji_astuty@Borobudur.co.id ${ }^{2}$, yancenter@yahoo.com³ $\}$ \\ ${ }^{1}$ Universitas Islam Negeri, Syarif Hidayatullah, Jakarta, Indonesia \\ ${ }^{2}$ University of Borobudur, Jakarta, Indonesia \\ ${ }^{3}$ Akademi Akuntansi Keuangan dan Perbankan Indonesia, Banten, Indonesia
}

\begin{abstract}
The development of Islamic banks along with sharia units from year to year reflects increase the public confidence to istishna mode of financing of sharia bank. This study aimed to determine the influence of deposits, equity, non-performing financing, and growth non-performing financing to istishna financing both on partial and simultaneous measurements. The sample selected in this study was sharia commercial banks operating in Indonesia and Malaysia. This research used purposive sampling method, the sampling research was includes BRI Syariah, Maybank, Mandiri Syariah, Muamalat, Malaysia Affin Islamic Bank Berhad. The analytical method used regression analysis of the balanced panel. The $\mathrm{f}$ test results showed that the variable of deposits, equity, non performing financing and growth non performing financing simultaneous had has positif effect on Istishna financing. The t test results showed deposit variable, equity, and growth non performing financing partially had has positif effect on the Istishna financing. The only non performing financing has a significant negative relationship to the variable of financing Istishna. While The coefficient of determination showed all independent variables contributed predominant percentage portion to the dependent variable. The remaining minor percentage portion might be influenced by other variables, which did not exists in this research such as Capital Adequacy Ratio, Loan Deposit Ratio, and the level of foreign currencies reserve owned by the banks etc.
\end{abstract}

Keywords: Istishna Financing, Deposit, Own Equity, Non Performing Financing, Growth Non Performing Financing

\section{Introduction}

The economy of a country is built by two sectors, namely the real sector and the monetary sector. The real sector is the economic sector which is concentrated in the manufacturing activities and service sectors. While the monetary sector is concentrated in the banking sector. Based on its operational system, Indonesian banking is divided into two systems. First, the conventional banking system dominated with the interest system, where another terms of interest is equal to usury, is the addition of the principal amount of the loan. Second, the sharia banking system operated based on the principles of Islamic sharia is in accordance to Islamic laws [1].

The concept of Islam is to maintain a balance between the real sector and the monetary sector, so the growth of financing will not be separated from the growth of the financial real sector. Therefore, the financing factor applied in sharia banking plays a very important 
position to maintain the stability towards the development of real sector that is closely linked with the lower middle-class society.

Sharia banking is basically the development of the Islamic economic concept, especially in the field of finance developed as a response from a group of economists and practitioners of Muslim banking that seeks to accommodate the insistence of various parties who want the existence of financial transaction services carried out in line with the moral values and principles of sharia Islam. In the face of monetary turmoil stained by the high interest rates, the existence of sharia banking is unshakeable since sharia banking is not based on the interest banking system [2].

The characteristics of sharia banking system operating on the basis of profit sharing principles provide an alternative to a mutually beneficial banking system for the community. Profitable here is that the party who has the funds (customers) but cannot manage it, then the second party which can manage the funds into a business. The profit and loss of the business will be divided according to an agreement, so that both parties can cooperate with each other. In its operational activities, Islamic banks also run the aspects of fairness in transactions. They also prioritize the values of togetherness in production and avoid the speculative activities in financial transactions [3].

Islamic banks operate as financial intermediaries like conventional banking, but all of the mechanisms of bank activities are should operate follow the Islamic laws and principle. Fund raising is conducted through savings and investments such as Al-Wadi'ah and Mudaraba. While the lending banking schemes introduced through various mode of contracts such as the principle of sale and purchase/Murabahah, Salam and Istishna mode of trade financing, the principle of rent which is Ijarah, and the principle of profit sharing the so called of Mudharabah and Musyarakah.

The existence of sharia banking is increasingly popular not only in Islamic countries but also in non-Islamic countries such as in African and Western countries. Sharia banking in Indonesia was firstly appeared in 1992 with the establishment of Bank Muamalat Indonesia as the first sharia bank in Indonesia [4].

The development of sharia banking in Indonesia tend to increase in relation to the increase of public knowledge on the value of various schemes introduced by sharia banking [5].

The rapid development of Islamic banks along with sharia units from year to year reflects the level of public trust which is better against sharia banks. The increase of public confidence was followed by the improvement of banking performance has made sharia banking known and become a conventional banking solution that has a considerable loss rate [6]. The concept of sharia banking based on profit sharing principles is considered acceptable than the conventional banks which still implement the system of interest in which the Islamic bank interest system is forbidden to the particular communities mostly Muslims.

\section{Discussion}

\subsection{Dependent Variables}

In this study, the dependent variable is the amount of Istishna financing in the channel of Sharia Commercial Banks in Indonesia as well as in Malaysia. Istishna from the various point of fiews means mode of trade financing system through ordering of goods or commodities with specific technical specification agreed by both parties with mode of payment based on particular agreement. 


\subsection{Independent Variables}

\subsubsection{Deposits}

The collection of Islamic bank funds from the public can be in the form of demand deposits, savings and deposits. Sharia operational principles applied in the collection of public funds are the principles of Wadi'ah/demand deposits and savings and Mudharabah/savings and deposits.

Demand Deposits are deposits withdrawals which may be made at any time by check, bilyetgiro other means of payment order, or by book-entry. Savings are deposits in which its withdrawals may only be made under certain agreed conditions but it cannot be withdrawn by check, bilyetgiro, and/or other equivalent means. Additionally, deposits are the withdrawal which may only be made at a specified time based on the depositors' deposit agreement with the bank [7].

From various sources of funds obtained by the bank where the third party funds consists of wadi'ah giro, mudharabah savings and mudharabah were the largest source of funds obtained by banks, it is appropriate for the bank to prepare the strategy of allocation of fund placement to achieve several goals, that are reaching enough profitability level and maintaining public trust by keeping the liquidity position safe .

\subsubsection{Capital/Equity}

Capital itself is traditionally defined as something that has the interests of the owner in a company. Based on the book value, capital is defined as net worth which is the difference between the book value and the assets minus the book value of the liabilities. The source of the capital of the bank can be obtained from the founders and shareholders. The shareholders invest their capital in the bank by earning the profit in the future, the bank as a business unit requires funds which is in the form of capital. In other words, bank capital is an important aspect to support all banking activities which include banking research and development, banking education and training as a means to increase the human resource competencies[8].

Since the operation of a bank is not one of those which are influenced by the condition of its capital adequacy, the own capital has a positive relationship with the ability of banks in financing. The greater capital owned by a bank, the greater the ability of banks do the various banking activities.

\section{Non-Performing Financing/NPF}

One of risks often faced by the banks is the non-payment of financing risk which has been given or often called the financing risk. Financing risks generally arise from various financing included into the category of problematic or NPF. The problematic caused by the management factor, economic condition, and other factors.

In maintaining the security of depositors, the central bank requires commercial banks to provide reserve requirements or anticipated costs against losses or Allowance for Earning Assets Losses. The ratio of NPF is aimed to measure the level of financing problems faced by sharia banks where the higher number of the ratio which indicates the sharia bank financing quality is getting worse. There are two main reasons for the increment of NPF that are economic crisis affect macroeconomic conditions, miss financial allocation and deliberate financing fraud [9]. The information on its performance derives from selected banks and the annual reports and related publications on general banking performaces in each country 


\subsubsection{Growth Non Performing Financing/GNPF}

Non Performing Financing remains a frightening aspect for the banks. In particular, an experience proves that one of the causes in the economic crisis is a poor banking performance. The high NPF greatly contributes to the poor performance of the banks. The growth of non performing funds or the so-called GNPF can also affect the value of financing in Islamic banks.

\section{Interconnected Linkages}

\subsection{Deposits With Istishna Financing}

Deposits or third party funds was collected by the banks from the public in the form of wadiah deposits, savings deposits, deposits and other forms of financing offers by Sharia Banks. The larger the existing savings or sources of funds, the bank then will be able to offer its funds through various mode of financing. In addition, deposits are also often associated with the liquidity within a bank. Bank Indonesia as a central bank requires every banks must having a minimum mandatory liquidity to amount of liabilities to third parties[10].

\subsection{Capital With Istishna Financing}

Capital itself is traditionally defined as something that has the interests of the owner in a company. In a bank, the source of the bank's capital can be obtained from the founders and shareholders. The shareholders invest their capital in the bank by earning the profit in the future, the bank as a business unit requires funds, which are in the form of capital. In other words, the bank capital is an important aspect for a business unit of the bank because the condition of its capital adequacy is one of factors which influence the bank whether to operate or not. Own capital has a positive relationship with the banks 'ability to operate all its activities, the greater the own capital owned by a bank, the greater the ability of banks to offer various mode of financing [11].

\subsection{NPF, GNPF with Financing of Istishna}

The ability of banks to overcome the risk of bad debts or default is very important aspect to achieve the high banking performance. Funds to cover the bad debts and default are from the bank capital, the bigger financial problem faced by the banks the greater the bank capital used to cover its problems. Non performing funds is one of the causes on the banks' difficulties in financing. The credit policy by the bank management should be simplified as a means to enhance the level of demand for financing, therefore the Bank should also avoid the decreased public demand for financing due to the long financing process and procedures. If its happens, the prospective customers will deals with another prudential banking having good service records and performances [12].

\section{Data Analysis Technique}

The data analyses of this study done through various approaches which consists of among other things, Estmation panel data regression model, Common Effect Model, Fixed Effect Model, Random Effect Model. Through three approaches expected to come up with valid correlation result and how far the relationship among variables [13]. 
The Calculation of Panel Data Regression Estimation Model consists of chow test, Hausman test, classic assumption test, normality test, heteroscedascity test, multicolliniarity test and Autocorrelation test. Chow test test is used to select one model on the panel data regression between fixed model effect with the common effect model. The hausman test aims to see random effects within the data panel, the classic assumption test will use four classical assumption tests. Normality test, as a means to see the coefficients and Jarque-Bera from Probability. Heteroscedasticity test aims to test whether there are variance and residual inequality of one observation to another observation in the regression model to avoid heteroscedasticity disorder. Multicollinearity test aims to test whether there is a correlation among independent variables. Autocorrelation test (autocorrelation) is to indicate the relationship between residual from one observation with other observation residual [14] .

Hypothesis testing compute using $\mathrm{F}$ test to find out whether the independent variables jointly have effect on the dependent variable or not. While the influence of one independent variable individually to the dependent variable using $\mathrm{T}$ test to measure whether independent variables individually have effect on the dependent variable and vice versa or not . The coefficient of determination is to find how strong the ability of the dependent variable is, and vice versa [15].

\section{Analysis and Discussion}

Based on the data computation the Probability value for Cross-section F is 0,0000 which means this value is below the 0.05 (significance or alpha level), so the most appropriate model for this research is the Fixed Effect compared to Common the Effect. The results of the computation of normality test the value of Jarque-Bera of 1.454011 is smaller than 2, and the probability value of 0.48 is greater than 0.05 . Thus, it can be concluded that the data in this study is normally distributed. The computation of multicolliniarity test the correlation coefficient is less than 0.85 then the model is assumed that it does not contain multicollinearity in the model.

The computation it can be concluded that there is no heteroscedasticity in this study. This data is from the value of Probability Chi-Square of 0.2843 where its value is greater than the value of 0.05 (significant level or alpha), meaning that the Ho is accepted.It is concluded that the heteroscedasticity did not occur in this study.

The autocorrelation test results can be seen from the value of Prob-F of 0.1307, where the value is greater than 0.05 (significant level or alpha).It can be concluded that there is no autocorrelation problem in this study.

The calculation result from $F$ test shows that the f-statistic probability value of 0.0000 is smaller than the significant level of 0.05.It can be concluded that the variable of Deposit, Equity and GNPF simultaneously influences the financing.

Based on the results of regression analysis of panel data above, it explains that the variable of Deposit influences the Financing Istishna at Sharia Banks in Indonesia and Malaysia. The value $t$ of arithmetic Deposits of 8.560542 is larger than the value table of 2.03951 and the probability value for 0.0000 Deposit is smaller than the level of significance of 0.05.It shows that the variable of deposit affects the significance of Istishna financing at sharia commercial banks in Indonesia and Malaysia.

The result of regression analysis of panel data explains that the variable of Equity effects on the Istishna financing at syariah bank. The value $t$ arithmetic Capital of 2.131157 is greater than $t$ table value of 2.03951 and the probability value for Capital of 0.0427 is smaller than 
the level of significance of 0.05.It shows that the variables Equity have an effect on the significance of Istishna financing at sharia commercial banks in Indonesia and Malaysia.

The result of panel data regression analysis explains that the GNPF variable has an effect on Istishna financing atsharia bank. The value of t arithmetic GNPF of 2.477318 is greater than t table of 2.03951 and the probability value for GNPF is 0.0201 smaller than the 0.05 significant level.It shows that GNPF has no significant effect on Istishna financing at sharia banks in Indonesia and Malaysia.

The Adjust R square value is 0.75 or also called coefficient of determination. The value of Adjust R square shows that $75 \%$ of the level of Deposits, Equity, NPF, and GNPF contributed to financing in sharia banking. While $25 \%$ contributed to the financing of other variables which are not examined in this study, such as Capital Adequacy Ratio, Fund Deposit Ratio, Inflation and so forth.

\section{Conclusions and Recommendations}

\subsection{Conclusions}

Based on the description of the results of research it can be concluded that the simultaneous test results of the Savings, Capital, Non Performing Financing and Growth Non Performing Financing jointly have a significant influence on the Istishna financing on sharia banking in Indonesia and Malaysia. The results of partial test, the variable of Deposit has a significant positive relationship to the variable financing of Istishna. The capital variable has a positive and significant effect on Istishna financing. While Non Performing Financing has a significant negative relationship to the variable of financing Istishna. The last partial test results of the Growth Non Performing Financing has a positive effect on the Istishna financing variable.

\subsection{Recommendations}

Related to this research, In order to obtain a more in-depth and comprehensive picture,the authors suggest several things, among others: Increasing more in income through financing, since basically financing through sale and purchase is strongly recommended by Islamic laws. Improving more and broadly distribution of financing in the area of trade and business, as a means to strengthen the Banks profitability and improve the banks performance expected come up with public trust and confidence to sharia Banks to manage the public funds. For the investors, should be couraged to invest their funds in sharia banking, confince them that there were various mode of financing in sharia bankings having comparable yields attractiveness to conventional banking. Since this study uses a period of six years period, it is desirable for further researchers to conduct a research with longer periods and uses more measurements variables to support this research. Technical data analysis in this research uses the method of regression analysis of panel data, authors expecting for the next researchers could explore more deeply and uses more advance technical approach in analyzing the data.

\section{References}

[1] G. M. Caporale, A. N. Çatık, M. H. Helmi, F. Menla Ali, and M. Tajik, "The bank lending channel in the Malaysian Islamic and conventional banking system," Glob. Financ. J., no. May, p. 100478, 2019.

[2] A. Salman and H. Nawaz, "Islamic financial system and conventional banking: A 
comparison," Arab Econ. Bus. J., vol. 13, no. 2, pp. 155-167, 2018.

[3] N. Alam, B. A. Hamid, and D. T. Tan, "Does competition make banks riskier in dual banking system," Borsa Istanbul Rev., vol. 19, pp. S34-S43, 2018.

[4] N. Alam, S. S. Binti Zainuddin, and S. A. R. Rizvi, "Ramifications of varying banking regulations on performance of Islamic Banks," Borsa Istanbul Rev., vol. 19, no. 1, pp. 49-64, 2019.

[5] S. A. R. Rizvi, P. K. Narayan, A. Sakti, and F. Syarifuddin, "Role of Islamic banks in Indonesian banking industry: an empirical exploration," Pacific Basin Financ. J., p. \#pagerange\#, 2019.

[6] A. M. Amran, R. A. Rahman, S. N. S. Yusof, and I. S. Mohamed, "The Current Practice of Islamic Microfinance Institutions' Accounting Information System via the Implementation of Mobile Banking," Procedia - Soc. Behav. Sci., vol. 145, pp. 81-87, 2014.

[7] C. Zehir, H. Yıldız, M. Köle, and D. Başar, "Superior Organizational Performance through SHRM Implications, Mediating Effect of Management Capability: An Implementation on Islamic Banking," Procedia - Soc. Behav. Sci., vol. 235, no. October, pp. 807-816, 2016.

[8] K. Hamilton et al., Where is the Wealth of Nations? 2006.

[9] S. Srairi, "Transparency and bank risk-taking in GCC Islamic banking," Borsa Istanbul Rev., vol. 19, pp. S64-S74, 2019.

[10] C. Suisse, “Global Wealth Report 2013,” Credit Suisse Res. Inst., no. October, pp. 2983, 2013.

[11] N. El-Bassiouny, "Where is 'Islamic marketing' heading?," J. Bus. Res., vol. 69, no. 2, pp. 569-578, 2016.

[12] M. Hosseini, J. Moore, M. Almaliki, A. Shahri, K. Phalp, and R. Ali, "Wisdom of the Crowd within enterprises: Practices and challenges," Comput. Networks, vol. 90, pp. 121-132, 2015.

[13] C. J. Clawson, "Fitting Branch Locations, Performance Standards, and Marketing Strategies to Local Conditions," J. Mark., vol. 38, no. 1, pp. 8-14, 1974.

[14] A. Bergsma and M. Ardelt, "Self-Reported Wisdom and Happiness: An Empirical Investigation," J. Happiness Stud., vol. 13, no. 3, pp. 481-499, 2012.

[15] R. La Porta, F. Lopez-de-SIlanes, A. Shleifer, and R. W. Vishny, "Law and Finance," J. Polit. Econ., vol. 106, no. 6, pp. 1113-1155, 1998. 